\title{
UPAYA DISASTER DIPLOMACY PEMERINTAH INDONESIA DI KONFLIK ACEH TAHUN 2005
}

\author{
Arfin Sudirman dan Naura Nabila Haryanto \\ Departemen Hubungan Internasional, Fakultas Ilmu Sosial dan Ilmu Politik, Universitas Padjadjaran \\ E-mail: arfin.sudirman@unpad.ac.id
}

\begin{abstract}
ABSTRAK, Bencana alam gempa bumi dan tsunami yang terjadi di Aceh tahun 2004 merupakan salah satu bencana alam terbesar yang terjadi di Indonesia. Selain itu, Aceh juga merupakan zona konflik yang dibatasi akses dengan komunitas internasional. Sejak tahun 1976 sampai tahun 2004, Aceh berfokus pada konflik berkepanjangan akibat usaha Pemerintah Indonesia dalam meredam perjuangan gerakan separatisme GAM. Namun, peristiwa bencana alam gempa bumi dan tsunami merupakan momentum titik balik konflik RI dengan GAM ke arah negosasi dan perdamaian yang menghasilkan Perjanjian Helsinski tahun 2005. Dengan menggunakan pendekatan Disaster Diplomacy dan metode kualitatif deskriptif analitis, artikel ini bertujuan untuk memahami upaya Pemerintah Indonesia memanfaatkan momentum bencana alam untuk mencapai perdamaian dengan GAM. Artikel ini menyimpulkan bahwasanya hambatan terhadap upaya diplomasi perdamaian di Aceh yang selama ini terjadi dapat dihilangkan akibat dampak destruktif bencana gempa bumi dan tsunami. Bencana ini membawa konflik mencapai titik jenuh hingga GAM tidak lagi memiliki posisi tawar yang kuat untuk memberontak kepada Pemerintah Indonesia. Sementara Pemerintah Indonesia pun sadar bahwa momentum ini dapat 'dimanfaatkan' untuk menyelesaikan konflik yang berlarut-larut.
\end{abstract}

Kata kunci: Pemerintah Indonesia; disaster diplomacy; GAM; dan tsunami Aceh.

\section{INDONESIA'S DISASTER DIPLOMACY EFFORT IN ACEH'S CONFLICT IN 2005}

\begin{abstract}
The earthquake and tsunami disaster that occurred in Aceh in 2004 is considered as one of the most devastated natural disasters occured in Indonesia. In addition, Aceh is also a conflicting zone that is restricted for international community. Since 1976 to 2004, Aceh focused on the prolonged conflicts caused by the Government of Indonesia's efforts to contain the GAM's separatist movement. However, the earthquake and tsunami disaster was regarded as the turning-point between Indonesia and GAM conflict towards the mutual negotiations and peace resolution that resulted in the Helsinki Agreement in 2005. Using the Disaster Diplomacy approach and qualitative analytical descriptive method, this article aims to understand the Indonesian Government's efforts to take advantage of natural disasters's momentum to attain peaceful resolution with GAM. This article concludes that the obstacles for peace diplomacy to be implemted in Aceh can be eliminated as a result of the destructive impact of the earthquake and tsunami disaster. This disaster brought the conflict to a point of saturation point where GAM had no longer have a strong bargaining position to rebel against the Government of Indonesia. While the Government of Indonesia is also aware that this momentum can be 'exploited' to resolve the protracted conflict.
\end{abstract}

Key words: the Indonesian Government; disaster diplomacy; disaster related activites; GAM, and the Aceh tsunami.

\section{PENDAHULUAN}

Gempa bumi sebesar 9.3 skala richter yang mengakibatkan terjadinya tsunami pada 26 Desember 2004 merupakan salah satu bencana alam terbesar di satu dekade terakhir (Kelman, 2016: 1-3). Gelombang tsunami mengakibatkan kerusakan hebat di ribuan kilometer garis pantai sepanjang Aceh, Sumatera Utara, dan pulau-pulau yang terletak di barat Indonesia. Indonesia merupakan negara yang terkena dampak kerusakan paling parah, dengan 164.891 korban tewas yang terkubur, 114.897 korban hilang, dan 412.438 korban terlantar (UNEP, 2005: 18). Dampak destruktif terkena pada hampir seluruh aspek kehidupan di Aceh, seperti ekonomi lokal, infrastruktur, dan administrasi (Masyrafah and McKeon, 2006: 1). Dalam pidatonya, Presiden SBY sebagai Presiden Indonesia saat itu, menuturkan bahwa total kerusakan properti publik maupun privat ialah sebesar 5 milyar dolar AS, atau seluruh produk domestik bruto Aceh (Yudhoyono, 2005: 432-434).

Selain karena terkena dampak destruktif paling buruk dibandingkan negara lainnya, salah satu bagian dari Indonesia - yaitu Aceh, juga merupakan zona konflik yang dibatasi akses dengan komunitas internasional.
Sejak tahun 1976 sampai tahun 2004, Aceh berfokus pada konflik yang hadir karena usaha Pemerintah Indonesia dalam meredam perjuangan gerakan separatisme Gerakan Aceh Merdeka (GAM) (Kweifio-Okai, 2014). Konflik tersebut menyebabkan Pemerintah Indonesia mendeklarasikan bahwa Aceh termasuk dalam daerah operasi militer (DOM) dan melarang non warga Aceh, baik masih merupakan warga negara Indonesia maupun bukan, untuk mengunjungi daerah tersebut (Masyrafah and McKeon, 2006: 4). Upaya resolusi konflik ini berbeda dengan apa yang ditawarkan Miall, Ramsbotham dan Woodhouse (dalam Sulaeman, 2010)) yang menyatakan bahwa terdapat banyak pendekatan alternatif mengenai resolusi konflik namun jarang dilakukan dengan memahami peristiwa atau pengetahuan local. Tulisan ini bertujuan untuk memahami upaya Pemerintah Indonesia memanfaatkan konsep disaster diplomacy untuk men-capai perdamaian antara kedua belah pihak dengan dihasilkannya Perjanjian Helsinki pada tujuh bulan kemudian, yaitu bulan Agustus tahun 2005.

Menurut Kelman (2012: 13) konsep disaster diplomacy pada dasarnya merupakan varian dari kajian diplomasi dengan menganalisis kemungkinan bencana 
alam dapat menciptakan peluang untuk memfasilitasi kerja sama aktor yang secara alaminya merupakan "musuh", atau tidak. Menurutnya, disaster diplomacy mengarahkan kepada penelitian tentang bagaimana dan mengapa aktivitas terkait kebencanaan dapat dan/atau tidak dapat menginduksi kerja sama antara aktor internasional yang secara alami bermusuhan (Kelman 2003, 110-111).

Konsep 'disaster diplomacy' dikembangkan dan dipopulerkan oleh Ilan Kelman dan Theo Koukis dalam 'Disaster Diplomacy' pada Cambridge Review of International Affairs yang diterbitkan di tahun 2000. Tulisan tersebut menganalisa empat tulisan ilmiah yang didasari oleh empat studi kasus yang berbeda melalui kacamata disaster diplomacy. Empat tulisan ilmiah tersebut merupakan tulisan dari Dr. James Ker-Lindsay yang membahas tentang studi kasus hubungan Yunani dan Turki pasca bencana gempa; Michael H. Glantz membahas tentang studi kasus badai yang menyelimuti Kuba-AS; Ailsa Holloway membahas tentang kekeringan di Afrika Selatan pada 1991-1993; dan Louise Comfort yang membandingkan ketiga studi kasus tersebut melalui complex adaptive systems framework.

Didasari dari berbagai studi kasus, Kelman dan Koukis menyimpulkan bahwa aktivitas terkait kebencanaan dapat mempengaruhi, mendukung, mendorong, atau bahkan menghalangi proses diplomasi. Di lain sisi, tidak seluruh bencana dapat memiliki pengaruh yang kuat terhadap suatu konflik. Aktivitas terkait kebencanaan dapat mendukung proses diplomasi apabila proses tersebut sudah dimulai sebelum adanya aktivitas terkait kebencanaan. Hal ini lah yang disebut sebagai konsep disaster diplomacy. (Kelman 2012, 14-15).

Aktivitas terkait kebencanaan sendiri digambarkan oleh Kelman sebagai aktivitas, perilaku, keputusan, dan nilai yang dianut dan diambil oleh manusia dalam menghindari atau menghadapi suatu bencana. Hal ini merupakan komponen analisis disaster diplomacy karena adanya bencana dengan aktivitas, perilaku, dan keputusan manusia, serta nilai yang dianut manusia dapat dianggap seperti siklus yang saling mempengaruhi satu dengan yang lainnya. Aktivitas terkait kebencanaan dapat terbagi menjadi dua, yaitu ketika sebelum terjadinya bencana dan setelah terjadinya bencana.

Pertama, aktivitas terkait kebencanaan sebelum terjadinya bencana terdiri dari pencegahan, perencanaan, mitigasi, persiapan, dan reduksi risiko bencana. Aktivitas, perilaku, dan keputusan manusia, serta nilai yang dianut oleh manusia dapat menimbulkan bencana bagi manusia, atau bahkan mengurangi risiko terjadinya bencana. Contoh, perilaku buang sampah sembarangan yang dilakukan manusia dapat menyumbat saluran air perkotaan sehingga menimbulkan banjir ketika musim hujan. Kedua, aktivitas terkait kebencanaan setelah terjadinya bencana yang terdiri dari bagaimana manusia merespon bencana tersebut, rekonstruksi, dan pemulihan keadaan setelah terjadinya bencana. Bencana dapat berpengaruh terhadap aktivitas, perilaku, dan keputusan manusia, serta nilai yang dianut oleh manusia. Sebaliknya, perilaku manusia dalam merespon bencana tersebut juga menentukan seberapa besar dan lama dampak destruktif yang harus dirasakan para korban terhadap bencana tersebut. Contoh, ketika bencana alam melanda negara A dan B yang bermusuhan, maka kedua negara tersebut akan saling memperlihatkan empati, yang dapat berupa bantuan kemanusiaan, sehingga hubungan kedua negara tersebut semakin membaik (Kelman 2012, 11-17).

Dalamjangka pendek, aktivitas terkaitkebencanaan dapat, namun tidak selalu, memiliki pengaruh pada proses diplomasi. Hal ini membuat pre-existing basis perlu untuk diketahui dalam menganalisa proses diplomasi. Pre-existing basis dapat berarti hubungan perdagangan, koneksi kultur, negosiasi perdamaian rahasia atau terbuka antara pihak yang berkonflik, atau bahkan joint sport events (Kelman, Disaster Diplomacy: How Disasters Affect Peace and Conflict 2012, 14).

Dalam jangka panjang dibandingkan aktivitas terkait kebencanaan, faktor non-bencana secara umum dilihat memiliki efek yang lebih signifikan pada proses diplomasi. Contohnya ialah ketidakpercayaan, perubahan dalam kepemimpinan suatu pemerintahan, atau keyakinan bahwa konflik masa lalu dapat mempengaruhi disasterrelated atau peace-related activities (Kelman, 2012: 14). Kelman membuat enam pertanyaan yang harus dapat dijawab dalam menganalisa studi kasus menggunakan konsep disaster diplomacy untuk mengembangkan kerangka analisis. Namun demikian, tulisan ini hanya akan membahas dua dari enam pertanyaan analisis atas pertimbangan signifikansi dengan studi kasus yang diangkat yaitu: Pertama, apakah aktivitas terkait kebencaaan menuntun kepada interaksi diplomasi?; kedua, apakah terbentuk diplomasi baru? Jika aktivitas terkait kebencanaan mempengaruhi proses diplomasi yang sedang berlangsung, maka hal tersebut dianggap sebagai katalis, bukan membentuk diplomasi baru. (Kelman, 2012: 15-16)

Disaster diplomacy merupakan konsep yang masih terus berkembang, dengan didasari dari fenomena yang digunakan sebagai alat untuk mengembangkan konsep tersebut. Menurut Sudirman dan Putra (2018), Disaster diplomacy menawarkan pendekatan alternatif dalam interaksi antar negara terutama karena sifat bencana alam yang tidak mengenal batas kedaulatan negara sehingga kerjasama, perjanjian perdamaian dan bantuan kemanusiaan dapat menjadi sebuah kepentingan kolektif negara-negara di dunia.

Dari berbagai studi kasus yang telah dibahas menggunakan konsep disaster diplomacy sebagai pisau analisis dalam penelitian Kelman, Kelman menyimpulkan bahwa aktivitas terkait kebencanaan belum pernah terlihat berhasil memproduksi hasil diplomasi baru atau menginisiasi usaha diplomasi baru, namun memiliki potensi sebagai katalis dalam aktivitas diplomasi yang 
telah berjalan dalam jangka pendek, dan tidak memiliki potensi untuk membuat aktivitas atau proses diplomasi baru dalam jangka panjang. Aktivitas terkait kebencanaan tidak membuat kesempatan diplomatik baru bagi para aktor untuk melakukan kerja sama, namun memiliki kemungkinan sebagai katalisator dalam aksi diplomasi.

Selain itu, pada artikel ini juga yang akan dibahas sebagai aktivitas terkait kebencanaan merupakan aktivitas atau kebijakan yang dipilih oleh manusia setelah terjadinya bencana, di mana terdiri dari bagaimana manusia merespon bencana tersebut, bagaimana mereka menentukan kebijakan dalam melakukan rekonstruksi dan rehabilitasi daerah yang terkena dampak destruktif, serta bagaimana kontribusi berbagai pihak dalam pemulihan keadaan setelah terjadinya bencana.

\section{METODE}

Metode penelitian yang digunakan dalam tulisan ini adalah metode penelitian deskriptif analitis yang menitikberatkan pada pemahaman dan persepsi subjektif peneliti sebagai seseorang yang memiliki latar belakang dan pengalaman sebagai seorang akademisi untuk melakukan interpretasi data dimana faktor subjektivitas ini tidak dapat dihindarkan dalam penelitian sosial (Stake, 2010: 11). Terdapat dua teknik pengumpulan data yang dilakukan oleh penulis dalam membahas tulisan ini. Pertama, menggunakan teknik keeping records, di mana mengumpulkan data dari dokumentasi sumber ilmiah, seperti buku, jurnal ilmiah, penelitian terdahulu, serta sumber valid lainnya - seperti situs resmi. Penulis menggunakan teknik ini untuk mengetahui perkembangan konsep disaster diplomacy melalui buku Disaster Diplomacy karya Ilan Kelman, dan situs resmi Ilan Kelman sebagai pengembang konsep disaster diplomacy, serta lini masa konflik beserta proses diplomasi Pemerintah Indonesia dan GAM, baik sebelum (dari tahun 1999) sampai setelah (sampai tahun 2005) terjadinya bencana tsunami yang melanda Aceh di tahun 2004.

Kedua, menggunakan teknik wawancara untuk memperoleh informasi dan interpretasi yang bersifat unik dan valid dari seorang narasumber. Narasumber pertama ialah Nezar Patria sebagai jurnalis asal Aceh dan saksi Perundingan Damai Helsinki pada 2005. Narasumber kedua ialah Bustanul Arifin sebagai peneliti senior dengan spesialisasi konflik Pemerintah Indonesia dan GAM. Dan narasumber ketiga ialah Ilan Kelman sebagai pengembang konsep disaster diplomacy. Wawancara dilakukan pada narasumber pertama dan kedua melalui wawancara tatap muka, sementara wawancara melalui email dilakukan kepada narasumber ketiga.

Teknik analisis data yang dilakukan setelah data terkumpul adalah pertama melakukan penyusunan data sesuai dengan kategori dari masing-masing data untuk memudahkan penggunaan sekaligus interpretasi data agar dapat bersifat terstruktur, efektif, dan efisien. Dan kedua melakukan penyortiran dan interpretasi data. Penyortiran data dilakukan untuk melihat kesinambungan antara pertanyaan penelitian yang dirumuskan oleh penulis dengan kumpulan data yang telah diseragamkan, dan interpretasi data dapat dilakukan dengan menggunakan konsep diplomacy dan disaster diplomacy untuk dijadikan sebagai pisau analisis oleh penulis.

\section{HASIL DAN PEMBAHASAN}

Untuk mengetahui apakah aktivitas terkait kebencaaan atau disaster related activities sebagai bagian dari Disaster Diplomacy diperlukan penjelasan mengenai respon Pemerintah Indonesia, GAM, dan komunitas internasional untuk menyimpulkan apakah peristiwa bencana alam sebagai respon menuntun kepada interaksi diplomasi.

Presiden SBY mengatakan bahwa tsunami yang terjadi di penghujung tahun akhir tahun 2004 menyebabkan tewasnya 200.000 korban jiwa di kawasan Asia dan Afrika. Ia mengatakan bahwa Indonesia merupakan negara yang terkena dampak destruktif dan kehilangan paling besar di antara negara-negara lainnya. Di Aceh dan Nias, terdapat 120.000 korban jiwa dengan 100.000 orang yang masih dinyatakan hilang. Tidak hanya kehilangan banyak korban jiwa, namun kerugian total dari dampak destruktif yang melanda properti publik maupun privat ialah sebesar 5 milyar dolar AS, atau seluruh produk domestik bruto Aceh. Seluruh sarana administrasi publik dan sarana umum hancur diluluhlantakkan oleh tsunami, sehingga seluruh kegiatan perekonomian di Aceh pun lumpuh (Yudhoyono, 2005: 432-434).

Pada hari terjadinya tsunami, yaitu 26 Desember 2004, Presiden SBY langsung mendeklarasikan bencana alam dan memerintahkan berbagai departemen dan kementerian untuk melakukan mobilisasi sumber daya yang tersedia sebagai respon keadaan darurat serta proses rehabilitasi dan rekonstruksi, serta menugaskan Badan Nasional Penanggulangan Bencana (BNPB atau dulu dikenal dengan Bakornas PB) untuk mengirimkan sumber daya yang dimiliki oleh Bakornas PB ke Aceh (Masyrafah and McKeon, 2008: 4)

Tidak hanya Presiden SBY, namun Wakil Presiden Jusuf Kalla juga memberikan respon terkait bencana sekaligus konflik pada akhir Desember 2004. Ia mengatakan kepada Hamid Awaluddin (2008: 24) sebagai Menteri Hukum dan HAM Republik Indonesia saat itu bahwa: "Aceh harus segera damai. Tidak mungkin suplai makanan bisa berjalan lancar kalau masih ada letusan senjata. Apa yang terjadi jika ada orang internasional yang tengah membantu Aceh tiba-tiba diculik atau terbunuh? Mereka berlarian pergi, membuat rakyat Aceh dan Nias kian menderita".

Dari tanggapan tersebut, dapat dilihat bahwa pemerintah pusat bermaksud untuk memulai dialog kembali dengan Aceh dengan tujuan akhir perdamaian 
antara kedua belah pihak dan dapat saling berkompromi dengan kepentingan masing-masing pihak. Dialog damai ini diperlukan untuk membantu korban bencana, karena konflik dapat menghambat bantuan untuk terdistribusi dengan baik.

Enam belas hari setelah terjadinya tsunami di Aceh, Wakil Presiden Jusuf Kalla mengirimkan memorandum resmi ke Presiden SBY dengan Nomor 02/WP/1/2005. Memorandum tersebut berisi kondisi Aceh paska tsunami, termasuk kondisi pasukan GAM. Ia menyampaikan bahwa korban yang meninggal dalam bencana yang berlangsung mencapai 100.000 orang. Bencana tersebut juga menimbulkan pengungsi sebanyak 1.000 .000 orang dengankerusakan bangunan sebanyak 100.000 unit. Ia juga menggambarkan bahwa secara finansial, usaha rehabilitasi bencana tersebut masih berada dalam jangkauan. Dalam memorandum ini, beliau melaporkan kepada Presiden SBY mengenai sumber dana yang mungkin bisa dibayangkan (Ali, Monoarfa dan Effendy, 2008: 13). Selain kondisi Aceh paska tsunami, ia melaporkan bahwa pada tanggal 7 Januari 2005, Wakil Presiden telah berbincang dengan Muzakkir Manaf sebagai Panglima GAM pada saat itu, dan menambahkan bahwa ikhtiar damai harus melibatkan kepemimpinan GAM yang ada di Swedia (Awaluddin, 2008: 33).

Tujuan dari dikeluarkannya memorandum tersebut ialah dorongan Wakil Presiden terhadap seluruh Pemerintah Indonesia dan GAM untuk bahu membahu membangun Aceh kembali paska tsunami. Arah memo tersebut ialah membuka dialog dengan GAM. Hal ini dapat dilihat dari kutipan memorandum tersebut: "...walau pun akibat operasi terpadu kekuatan GAM telah berkuran 50\%, tapi tetap berbahaya, apabila mereka melakukan aksi teror, penembakan, dan penculikan, khususnya pada orang asing. Komunikasi dengan Panglima GAM Muzakkir Manaf untuk menyelesaikan masalah secara damai telah terjadi pada 7 Januari 2005, tapi kemungkinan untuk itu tetap tergantung pada putusan politik GAM Swedia." (Ali, Monoarfa dan Effendy, 2008: 14).

Wakil Presiden juga menyebutkan bahwa upaya dialog damai dapat dilakukan dengan difasilitasi oleh mantan Presiden Finlandia, yaitu Presiden Martti Ahtisaari. Wakil Presiden yakin dengan himpunan pengalaman Presiden Ahtisaari dan CMI, karena organisasi ini pernah memfasilitasi dialog informal dan mediasi di Afrika, Irak, Irlandia Utara, dan Asia Tengah. Hal ini mendorong Wapres Jusuf Kalla untuk mempertimbangkan bahwa ia merupakan orang yang tepat sebagai juru damai (Ali, Monoarfa and Effendy, 2008: 17-18). Pada memorandum tersebut, tercatat bahwa para pemimpin GAM, yaitu Malik Mahmud, Zaini Abdullah, dan Bachtiar Abdullah sudah bertemu dengan Ahtisaari dan menyatakan siap melakukan perundingan damai dengan Pemerintah Indonesia (Awaluddin, 2008: 33).

Wakil Presiden tidak hanya memikirkan, menentukan, dan merencanakan siapa fasilitator mediasi yang tepat dialog damai antara kedua belah pihak. Ia juga menekankan bahwa negosiasi dengan GAM berkisar pada tiga hal pokok, yaitu amnesti, tawaran kesejahteraan, serta pembangunan politik dan program pemerintah pusat kepada Aceh secara menyeluruh. Ia juga mengatakan bahwa sebelum seluruh upaya mengenai rekonstruksi bencana dilaksanakan, maka upaya perdamaian harus dilaksanakan secepatnya agar TNI dan pihak internasional dapat bersama bekerja (Ali, Monoarfa dan Effendy, 2008: 27).

Tidak hanya Wakil Presiden Jusuf Kalla yang menunjukkan usaha dan komitmennya agar kedua belah pihak berdamai setelah bencana tsunami, Presiden SBY menyampaikan bahwa Pemerintah Indonesia bekerja dua kali lebih keras untuk menghasilkan Master Plan - yang pengerjaannya akan diawasi oleh Badan Perencanaan Pembangunan Nasional (Bappenas), dalam rehabilitasi dan rekonstruksi Aceh. Pemerintah Indonesia juga membuat Badan Pelaksana Rehabilitasi dan Rekonstruksi Aceh-Nias (BAPEL) untuk melakukan implementasi terhadap strategi dari Master Plan tersebut dengan program yang konkret (Yudhoyono, 2005: 432-434). Master Plan dan badan pengurus khusus yang menangani rekonstruksi dan rehabilitasi Aceh paska tsunami ini bertujuan untuk membangun kembali Aceh, dengan ikut mendorong seluruh komunitas internasional maupun pihak yang bertikai untuk memprioritaskan pembangunan dibandingkan kepentingan masing-masing terhadap konflik yang ada.

Ada pun Master Plan tersebut memiliki lima pilar strategi. Pertama, mengembalikan infrastruktur publik seperti jalan dan sekolah. Kedua, mengembalikan fasilitas publik untuk mendukung aktivitas ekonomi, seperti pasar. Ketiga, melakukan stimulasi terhadap ekonomi lokal, seperti menciptakan lapangan pekerjaan baru. Keempat, memberikan keamanan lanjutan bagi komunitas Aceh untuk mengantisipasi bencana alam selanjutnya apabila akan datang (Yudhoyono, 2005: 435-436).

Selain itu, pada wawancara penulis dengan Bustanul Arifin, ia menyebutkan bahwa TNI yang sedang berada di Aceh turut membantu dalam merespon bencana tersebut karena saat itu masih banyak TNI yang belum sempat dipulangkan kembali ke ibukota karena pernah dikirim oleh Presiden Megawati pada operasi militer di tahun 2003. Aktivitas bantuan ini merupakan fungsi TNI untuk membantu apabila ada bencana alam atau proyek sosial di suatu daerah.

Selain Pemerintah Indonesia, komunitas internasional turut memberikan respon bantuan untuk Indonesia mengingat Aceh merupakan daerah yang terkena dampak destruktif paling parah di antara daerah atau negara-negara lain yang ikut merasakan dampak tsunami. Komunitas internasional mengakui bahwa dukungan yang diberikan komunitas internasional merupakan respon internasional terbesar dalam merespon bencana alam, melibatkan jumlah donor terbanyak, dan merupakan respon finansial tercepat terhadap bencana (Flint and Goyder, 2006: 7). 
Koordinasi bantuan lokal maupun internasional dipimpin oleh Bakornas PB dengan United Nations Office for the Coordination of Humanitarian Affairs (UN OCHA) (Flint and Goyder, 2006: 4).

UN's Financial Tracking System melaporkan bahwa bantuan internasional dalam merespon bencana ini dialokasikan paling banyak kepada Indonesia, yaitu sejumlah 1 milyar dolar AS, dengan AS, Australia, dan Jepang sebagai sebagai pendonor resmi pemerintah dengan kuantifikasi kontributor paling banyak dalam bencana ini (Kweifio-Okai, 2014). Perserikatan BangsaBangsa (PBB) memberikan dana sebesar 1.1 milyar dolar AS untuk menyediakan makanan, air bersih, obat-obatan, dan penampungan sementara untuk korban. George Bush Senior dan Bill Cinton juga memberikan bantuan dengan membuat platform yang menampung dana bantuan khusus tsunami. Selain itu, Sekretaris Jendral PBB, Kofi Annan, menunjuk Presiden Bill Clinton sebagai Special Envoy for Tsunami Recovery selama dua tahun, untuk menstabilkan keinginan politik dari berbagai lembaga, baik pemerintah maupun non-pemerintah, dalam upaya pemulihan (The Parliament of the Commonwealth of Australia, 2006). Bantuan dana ini dilaporkan dengan transparan dan bertanggung jawab sesuai dengan komitmen Presiden SBY. Pemerintah Indonesia mempublikasikan data tentang dana tersebut dalam situs e-Aceh yang diurus oleh Bappenas (Yudhoyono, 2005: 435).

Dukungan dari komunitas internasional tidak hanya berupa dana maupun tenaga. World Bank, Asia Development Bank, Australia, Jepang, dan AS juga menunjukkan dukungannya dengan memberikan saran terhadap implementasi dari Master Plan dan BAPEL pada beberapa lokakarya yang diadakan oleh Pemerintah Indonesia (Yudhoyono, 2005: 434-435).

Kesadaran bahwa perdamaian antara kedua belah pihak itu penting demi kelancaran rehabilitasi dan rekonstruksi tidak hanya ditunjukkan oleh Pemerintah Indonesia dan komunitas internasional. Muhammad Nazar sebagai Ketua SIRA saat itu, mengirimkan surat untuk untuk Presiden dan Perdana Menteri GAM, yaitu Malik Mahmud. Surat tersebut berisi dorongan dan desakan oleh Muhammad Nazar kepada semua pihak untuk segera memajukan kembali proses perdamaian dan menjadikan bencana tsunami untuk menegakkan kebebasan, keadilan, HAM dan perdamaian di Aceh. Ia juga menyampaikan bahwa bencana tersebut harus dijadikan titik balik oleh semua pihak untuk menggapai tujuan yang mulia (Ali, Monoarfa dan Effendy, 2008: 23).

Disebutkan oleh Bustanul Arifin dalam wawancaranya dengan penulis, GAM vakum atau tidak melakukan aktivitasnya selama beberapa bulan GAM fokus untuk memikirkan bagaimana cara untuk membangun Aceh kembali. Ketika TNI dan GAM bahu membahu untuk membangun kembali Aceh paska bencana, mereka tidak memikirkan identitas masingmasing karena lebih berfokus bagaimana cara untuk bisa bertahan dari situasi paska bencana. Sementara itu, Nezar Patria sebagai sumber lainnya juga mengatakan bahwa GAM menyambut dengan baik bantuan yang datang ke Aceh, baik bantuan internasional maupun bantuan yang datang dari Indonesia. GAM sudah tidak mengkotakkotakkan bantuan tersebut dengan menganggap bahwa bantuan tersebut ada yang datang dari pihak musuh. Hal ini dikarenakan GAM sudah memprioritaskan untuk melakukan rekonstruksi paska bencana terhadap Aceh, dan hal tersebut dapat dilakukan dengan efektif apabila GAM mengesampingkan benturan kepentingannya dengan Pemerintah Indonesia.

Kesimpulan tersebut terlihat dari bagaimana Presiden SBY langsung memerintahkan berbagai departemen dan kementerian untuk melakukan mobilisasi sumber daya yang tersedia sebagai respon keadaan darurat serta proses rehabilitasi dan rekonstruksi, serta menugaskan Bakornas PB untuk mengirimkan sumber daya ke Aceh. TNI yang dilaporkan oleh LSM internasional sebagai bagian dari Pemerintah Indonesia yang berkontribusi pada tingginya angka korban konflik, juga langsung membantu warga Aceh untuk bertahan hidup selama proses rehabilitasi dan rekonstruksi berlangsung, tanpa 'mengkotak-kotakan' bahwa mereka merupakan Pemerintah Indonesia dan membahas konflik yang sebenarnya masih berlangsung. Selain itu, Wakil Presiden Jusuf Kalla juga langsung memiliki inisiatif untuk mengirim memorandum yang berisi dorongan bagi Pemerintah Indonesia untuk segera melakukan dialog damai dengan GAM, demi memperlancar terdistribusinya bantuan lokal maupun internasional ke Aceh. Wakil Presiden Jusuf Kalla sadar bahwa proses rehabilitasi dan rekonstruksi Aceh membutuhkan waktu yang lama, tidak hanya setahun atau dua tahun. Karena hal tersebut, beliau mendorong Pemerintah Indonesia untuk secepatnya berinisiatif mengadakan dialog damai dengan GAM. Ia sadar bahwa Pemerintah Indonesia harus memiliki inisiatif dalam memulai kembali dialog damai antara Pemerintah Indonesia dengan GAM untuk mencapai kesepakatan damai dengan sama-sama saling berkompromi terhadap kepentingan masing-masing pihak. Hal ini dikarenakan dalam membantu warga Aceh dalam menghadapi dampak yang ditimbulkan oleh tsunami, diperlukan kelancaran komunikasi antara Pemerintah Indonesia.

Inisiatif ini berbuah hasil, karena pada bulan Januari, dialog damai pertama antara kedua belah pihak dengan difasilitasi oleh CMI, berhasil diadakan. Inisiatif tersebut termasuk sebagai upaya Pemerintah Indonesia untuk melakukan diplomasi sesuai dengan fungsi diplomasi yang dipaparkan oleh Hedley Bull, karena negosiasi tersebut diadakan untuk memfasilitasi komunikasi antara pemimpin politik suatu negara dengan entitas internasional lain dalam politik dunia, di mana GAM sebagai gerakan separatis termasuk dalam entitas internasional lain. Selain itu, negosiasi ini juga bermaksud untuk menyelesaikan gesekan antara Pemerintah Indonesia sebagai aktor negara 
dengan aktor lain dalam hubungan internasional, karena komunitas internasional telah memberikan perhatian pada konflik ini. Hal ini dapat dilihat dari dukungan Pemerintah Libya untuk melatih pasukan militer GAM, dan berbagai laporan dari organisasi internasional - seperti Amnesty International dan Human Rights Watch, terhadap konflik tersebut.

Selain itu, pada era SBY ini negosiasi untuk mencapai kesepakatan bersama dalam penyelesaian konflik juga tertuang dalam Perjanjian Helsinki, sebagai sebuah perjanjian yang dilahirkan untuk melakukan kompensasi kepentingan masing-masing. Proses negosiasi selama tujuh bulan berhasil melahirkan perjanjian yang menyelesaikan konflik tersebut, sekaligus acuan proses rehabilitasi dan rekonstruksi Aceh dari konflik maupun bencana tsunami. Dalam Perjanjian Helsinki, secara eksplisit disebutkan bahwa perjanjian tersebut hadir untuk memudahkan kedua belah pihak dalam proses rehabilitasi dan rekonstruksi paska bencana, karena hal itu maka dapat disebutkan bahwa aktivitas terkait kebencanaan mendorong lahirnya Perjanjian Helsinki. Hal ini juga yang menjadi karakteristik dari kebijakan luar negeri SBY yang konstruktivis dengan memprioritaskan agenda peace-maker, confidence builder, problem solver dan bridge builder dengan bekerja sama dengan komunitas luar negeri untuk berbagai macam persoalan di dalam negeri (Yani, 2009).

Pertanyaan kedua untuk mengembangkan studi kasus ini pada kerangka disaster diplomacy ialah mengetahui apakah diplomasi yang dimaksud merupakan bentukan diplomasi baru. Karena apabila bukan, maka aktivitas terkait kebencanaan dianggap sebagai katalis proses diplomasi, bukan pembentuk diplomasi baru. Untuk menjawab pertanyaan ini, maka kita harus melihat lini masa konflik dan upaya kedua belah pihak untuk menyelesaikan konflik ini, dan apa yang membuat keduanya akhirnya menyepakati Perjanjian Helsinki yang menjadi dasar pengaturan pemerintahan di Aceh hingga sekarang.

Upaya Pemerintah Indonesia untuk menyelesaikan konflik secara damai dan tidak menggunakan kekuatan militer untuk meredam gerakan separatis GAM sudah mulai terlihat sejak Orde Baru runtuh. Presiden pertama yang menggantikan Presiden Soeharto ialah Presiden Habibie, di mana langsung menunjukkan itikad baik untuk menyelesaikan konflik tanpa menggunakan kekuatan militer. Usaha Presiden Habibie untuk mengunjungi Aceh dan meminta maaf atas berbagai kekejaman yang terjadi saat operasi DOM, memulai pendataan pelanggaran HAM, mengirim penyelidik kasus HAM, dan membebaskan ratusan tahanan politik Aceh, termasuk fungsi diplomasi karena Presiden Habibie berusaha untuk membuka kesempatan komunikasi antara pemimpin politik suatu negara dengan gerakan separatis sebagai entitas internasional. Ia juga memberikan status otonomi spesial kepada Aceh seperti telah dipaparkan, dan usaha ini dapat dikategorikan sebagai fungsi diplomasi karena
Presiden Habibie telah melakukan upaya tersebut untuk mengurangi intensitas konflik. Sayangnya, usaha ini belum membuahkan hasil karena eskalasi konflik masih meningkat.

Setelah Presiden Habibie, Presiden Abdurrahman Wahid merupakan Presiden Indonesia berusaha meredam konflik dengan meminta bantuan komunitas internasional untuk memfasilitasi konflik, yaitu HDC. HDC bersedia untuk turut andil dalam diplomasi antara kedua belah pihak, yaitu memfasilitasi dialog antara Pemerintah Indonesia dengan GAM. Usaha untuk menyudahi gesekan entitas internasional sesuai fungsi diplomasi Hedley Bull ini membuahkan hasil, yaitu Nota Kesepahaman Jeda Kemanusiaan sebagai perjanjian gencatan senjata untuk kedua belah pihak agar bantuan kemanusiaan kepada warga Aceh sebagai korban konflik dapat terdistribusi dengan baik, dan diimplementasikan dengan dua periode waktu implementasi masing-masing tiga bulan. Namun, perjanjian ini juga belum berhasil mendamaikan kedua belah pihak, bahkan eskalasi konflik semakin meningkat. Tidak menyerah, Presiden Abdurrahman Wahid berusaha menuruti keinginan GAM demi eskalasi konflik menurun. Ia mengeluarkan Instruksi Presiden yang berisi perintah kepada Wakil Presiden dan Kementerian untuk melakukan langkah komprehensif dalam menyelesaikan konflik.

Instruksi tersebutmasih belum berhasilmemfasilitasi dan mempertemukan kepentingan kedua belah pihak agar gesekan dapat berkurang. Dialog damai dengan difasilitasi oleh HDC berlanjut, dan proses diplomasi ini membuahkan perjanjian baru dengan nama COHA. Dalam perjanjian ini, kedua belah pihak bersepakat untuk menghentikan permusuhan, dan GAM telah menerima hak otonomi daerah yang ditawarkan oleh Pemerintah Indonesia.

Sayangnya, terdapat perbedaan penafsiran antara Pemerintah Indonesia, GAM, dan HDC sebagai mediator, sehingga keadaan konflik masih memburuk. Jumlah kasus yang dihitung sebagai on going incident ketika itu ialah 1.216 kasus, dengan 1.113 kasus yang belum diinvestigasi (StafOperasi Markas Besar TNI 2004, 52-53). Pemerintah Indonesia mengartikan bahwa dengan adanya perjanjian ini, maka GAM dapat dihilangkan karena Pemerintah Indonesia akan melanjutkan pembangunan di Aceh yang masih dalam bingkai Negara Kesatuan Republik Indonesia (NKRI) (Staf Operasi Markas Besar TNI 2004, 47). Sementara pihak GAM menafsirkan hak otonomi khusus dan pelaksanaan pemilu yang demokratis merupakan langkah awal adanya pemilihan pemerintahan Negara Aceh Merdeka, bukan pemilihan umum secara nasional seperti yang diinterpretasikan oleh Pemerintah Indonesia (Staf Operasi Markas Besar TNI 2004, 47). Dari sisi HDC, sebagai mediator negosiasi HDC masih mengabaikan teriakan yel-yel kemerdekaan Negara Aceh Merdeka atau tindakan yang tidak menghormati TNI atau Polri di Aceh. JDC mengira bahwa pembentukan komite pengawasan sebagai implementasi Jeda Kemanusiaan 
hanya menyentuh aspek keamanan, bukan aspek politik (Staf Operasi Markas Besar TNI 2004, 48). Usaha Pemerintah Indonesia masih berlanjut. Hal ini dibuktikan dengan tetap melakukan upaya damai sebagai ganti dari kegagalan COHA dengan mengadakan pertemuan di Tokyo, Jepang. Namun, pertemuan ini juga gagal.

Dialog damai dan mediasi yang menghasilkan kedua perjanjian tersebut belum berhasil mendamaikan kedua belah pihak. Hal ini disebabkan kedua belah pihak masih melanggar isi kedua perjanjian tersebut. Masih terdapat kesalahpahaman antara kedua belah pihak - seperti definisi gencatan senjata dan apakah pengibaran bendera GAM melanggar perjanjian tersebut atau tidak. Patroli polisi dan operasi sweeping masih sering dilakukan di Aceh, dan hal tersebut malah sering menimbulkan bentrok dengan pejuang GAM. Pemerintah dan militer juga mengkritik bahwa keinginan GAM untuk melakukan mediasi yang diawasi oleh komunitas internasional ini menguntungkan GAM sebagai usahanya dalam internasionalisasi (Aspinall and Crouch 2003, 87-98). Perbedaan persepsi dasar serta kurangnya kepercayaan antara kedua belah pihak, menjadikan implementasi perjanjian sebagai hasil dialog tidak sesuai yang diharapkan dan sangat berbeda dengan keadaan di lapangan (Patria and Wandi 2015, 4-5).

Melihat usaha penyelesaian konflik tanpa menggunakan kekuatan militer yang dilakukan oleh Pemerintah Indonesia, diplomasi baru tidak terbentu, karena preexisting basis dari diplomasi telah ada sejak jatuhnya Orde Baru. Pada wawancaranya dengan penulis, Bustanul Arifin memverifikasi data ini dengan mengatakan bahwa upaya damai yang telah dilakukan oleh Pemerintah Indonesia belum berhasil, sampai dilakukannya dialog damai yang dapat menuntun pada lahirnya Perjanjian Helsinki. Alasan mengapa Perjanjian Helsinki lahir ialah karena masih adanya keinginan besar dari GAM untuk merdeka.

Bencana tsunami merupakan momentum diplomatik bagi kedua belah pihak untuk mempercepat proses penyelesaian konflik. Terjadinya tsunami termasuk ke dalam tenggat waktu praktikal, di mana momentum ditentukan oleh suatu kejadian yang tidak dapat dikontrol oleh kedua belah pihak. Korban yang berjatuhan diakibatkan bencana tsunami juga lebih banyak jika dibandingkan dengan konflik yang belum berhasil diselesaikan selama 40 tahun. Fakta ini mendorong Pemerintah Indonesia, dengan inisiasi dari Wakil Presiden Jusuf Kalla, untuk segera menyelesaikan konflik demi lancarnya distribusi bantuan dari komunitas internasional untuk korban bencana untuk tetap bertahan hidup sekaligus melakukan proses pemulihan Aceh.

Dalam wawancara penulis dengan Nezar Patria dan Bustanul Arifin, keduanya mengatakan bahwa perbandingan jumlah korban konflik Aceh dan bencana tsunami mendorong Pemerintah Indonesia dan GAM untuk tidak mengedepankan kepentingan masing-masing dahulu. Bencana tsunami berhasil merubah ideologi Pemerintah Indonesia dan GAM untuk damai. Tadinya, kedua belah pihak bersikeras untuk mempertahankan kepentingan masing-masing tanpa kompromi. Dikarenakan alasan dasar, yaitu ketidakadilan yang dirasakan oleh warga Aceh terhadap pembangunan di Indonesia, maka GAM bersikeras untuk memerdekakan Aceh dari Indonesia. Namun, tsunami mendorong kedua belah pihak untuk mengesampingkan kepentingan tersebut dengan memprioritaskan rekonstruksi Aceh, karena rekonstruksi tersebut dapat berjalan lancar apabila kedua belah pihak berdamai sehingga komunikasi antara kedua belah pihak menjadi lancar. Pendirian GAM untuk merdeka tidak sekuat sebelum terjadinya tsunami, karena mereka sadar bahwa jika Aceh menjadi negara yang independen, maka warga Aceh belum tentu dapat berdiri sendiri dalam memulihkan kondisi Aceh seperti sebelum terkena dampak destruktif bencana tsunami. Bustanul Arifin bencana tsunami berhasil merubah pola pikir para anggota GAM dan Pemerintah Indonesia. Warga Aceh, termasuk anggota GAM berfokus pada bagaimana mereka dapat membangun kembaliAceh, begitu pula dengan Pemerintah Indonesia. Pemerintah Indonesia merasa mereka tidak dapat memaksa Aceh untuk berdamai, terutama melalui cara militer, karena bencana tsunami melahirkan sense of humanity antara kedua belah pihak. Bencana alam dapat memiliki pengaruh terhadap lahirnya atau berubahnya suatu kebijakan, karena kebijakan harus dicocokkan untuk menyelesaikan suatu permasalahan yang sedang terjadi pada negara.

Berdasarkan pemaparan di atas, dapat disimpulkan bahwa aktivitas terkait kebencanaan tidak melahirkan proses diplomasi baru. Namun, demi kelancaran terdistribusinya bantuan lokal dan internasional untuk melakukan rekonstruksi dan rehabilitasi Aceh paska tsunami, maka diperlukan komunikasi yang lancar antara Pemerintah Indonesia dan warga Aceh, termasuk GAM. Aktivitas terkait kebencanaan dianggap memberi pengaruh - dapat dianggap pula sebagai pendorong atau katalis, agar kedua belah pihak menyelesaikan 40 tahun konflik dengan melaksanakan dialog damai selama 7 bulan. Bencana tsunami merupakan momentum diplomatik bagi kedua belah pihak untuk.

\section{SIMPULAN}

Dengan demikian, untuk menjawab pertanyaan dalam artikel ini yaitu: pertama, apakah aktivitas terkait kebencaaan menuntun kepada interaksi diplomasi? Tulisan ini menyimpulkan bahwa interaksi diplomasi pasca bencana terjadi pada saat Pemerintah Indonesia dan CMI bekerjasama dan bertindak sebagai fasilitator dialog damai, serta keinginan GAM untuk membangun kembali Aceh, sudah cukup memanfaatkan diplomasi menjadi hasil atau sebuah perdamaian sehingga bisa "menjinakkan" GAM dengan mengakomodir kepentingan masing-masing. Pada pertanyaan penelitian kedua, apakah terbentuk diplomasi baru? Tulisan ini menyimpulkan bahwa setelah upaya persuasif maupun represif yang telah dilakukan sejak Presiden Soeharto hingga Presiden SBY tidak terlalu memberikan dampak berarti terhadap resolusi 
konflik dan upaya mencapai perdamaian dengan GAM. Dampak menghancurkannya bencana gempa bumi dan tsunami tahun 2004 menuntut kedua belah pihak untuk segera berdamai, karena lancarnya distribusi bantuan lokal maupun internasional dalam rekonstruksi dan rehabilitasi Aceh paska tsunami hanya akan dapat dicapai apabila komunikasi dan negosiasi antara kedua belah pihak lancar. Bencana ini membuat perjuangan GAM pada akhirnya mencapai titik jenuh karena dampak destruktif yang ditimbulkan tsunami kepada Aceh. GAM tidak lagi memiliki posisi tawar yang kuat untuk memberontak kepada Pemerintah Indonesia, dan menjadikan Aceh menjadi negara independen. Sementara Pemerintah Indonesia pun sadar bahwa keadaan ini dapat 'dimanfaatkan' untuk menyelesaikan konflik yang bertahun-tahun telah terjadi.

Bencana yang hadir di penghujung tahun 2004 ini dapat mengubah pemikiran Pemerintah Indonesia dan GAM, untuk dapat berkompromi dengan kepentingan masingmasing, dan melahirkan Perjanjian Helsinki pada tahun 2005 untuk mengakomodir kepentingan antara kedua belah pihak yang berkonflik sehingga konflik tersebut selesai, dan damai di Aceh dapat diraih kembali setelah 40 tahun lamanya.

\section{DAFTAR PUSTAKA}

Amnesty International. (1993). Shock Therapy: Restoring Order in Aceh. Amnesty International.

Arifin, B. (2017) Interview by Naura Nabila Haryanto. Situasi Konflik antara Pemerintah Indonesia dengan GAM (Mei 12, 2017).

Aspinall, E. \& Crouch, H. (2003) The Aceh Peace Process. Why It Failed. Washington DC.: East-West Center.

Awaluddin, H. (2008) Damai di Aceh: Catatan Perdamaian RI - GAM di Helsinki . Center for Stategic and International Studies (CSIS).

Bull, H. (2002). The Anarchical Society: A Study of Order in World Politics . 3rd edition. New York: Palgrave.

Centre for Humanitarian Dialogue. About. 2005. https:// www.hdcentre.org/who-we-are/about/ (accessed Desember 12, 2016).

CNN. Aceh: A Timeline of Insurgency. May 19, 2003. http://edition.cnn.com/2003/WORLD/asiapcf/ southeast/05/19/aceh.timeline/ (accessed May 18, 2017).

Flint, M. \& Goyder, H. (2006). Funding the Tsunami Response. Tsunami Evaluation Coalition.

Gorman, D. \& Kivimäki, T. (2008). Non-Governmental Actors in Peace Process: The Case of Aceh. Jenewa: The Centre for Humanitarian Dialogue.

Gorman, D. \& Kivimäki, T. (2008). Non-Governmental Actors in Peace Processes: The Case of Aceh. Case Study, Geneva: TheCentre for Humanitarian Dialogue.
Human Rights Watch. (1990). Indonesia: Human Rights Abuses in Aceh. Human Rights Watch.

Kelman, I. (2003). Beyond Disaster, Beyond Diplomacy. In Natural Disasters and Development in a Globalizing World, by Mark Pelling, edited by Mark Pelling. New York : Routledge.

Kelman, I. (2016). Catastrophe and Conflict: Disaster Diplomacy and Its Foreign Policy Implications. Diplomacy and Foreign Policy, 1, (1), 1-2.

- (2012). Disaster Diplomacy: How Disasters Affect Peace and Conflict. New York : Routledge.

Kweifio-Okai, Carla. (2016). Where Did the Indian Ocean Tsunami Aid Money Go?. Desember 25, 2014. https://www.theguardian.com/globaldevelopment/2014/dec/25/where-did-indian-oceantsunami-aid-money-go (accessed Januari 17, 2016).

Masyrafah, H. \& Jock MJA McKeon. (2006). PostTsunami Aid Effectiveness in Aceh. Wolfensohn Center for Development.

Masyrafah, H. \& Jock MJA McKeon. (2008). PostTsunami Aid Effectiveness in Aceh: Proliferation and Coordination in Reconstruction. Wolfensohn Center for Development, Brookings Global Economy and Development.

Patria, N. \& Wandi, A. (2015). "The Rebels, the State and the People: Inclusivity in the Aceh Peace Process." Inclusive Political Statements Paper.

Staf Operasi Markas Besar TNI. (2004) COHA, Suatu Penyelesaian Konflik di Aceh. Jakarta: Markas Besar TNI.

Stake, R.E. (2010) Qualitative Research: Studying How Things Work. The Guilford Press.

Sudirman, A. \& Cahya, P.A. (2018). Disaster Diplomacy as an Alternative Approach for Indonesia's Instrument of Foreign Policy in ASEAN. Jurnal Ilmiah Hubungan Internasional, 14, (1), 9.

Sulaeman, M. (2010). Dasar-dasar Konflik dan Model Resolusi Konflik pada Masyarakat Desa Pantura Jabar. Sosiohumaniora, 12, (2), 178

The Parliament of the Commonwealth of Australia. Australia's Response to the Indian Ocean Tsunami. Joint Standing Committee on Foreign Affairs, Defence and Trade of Australia, Canberra: Commonwealth of Australia, 2006.

Yani, M.Y. (2009). Change and Continuity in Indonesian Foreign Policy. Sosiohumaniora, 11, (1), 12

Yudhoyono, S.B. (2005). Rebuilding Aceh. In Transforming Indonesia: Selected International Speeches, by Dr. Susilo Bambang Yudhoyono, edited by Dino Patti Djalal. Jakarta: PT Gramedia .

Yudhoyono, S.B. (2001). interview by Kantor Menko Polsoskam. Aceh Perlu Keadilan, Kesejahteraan, dan Keamanan. 